\title{
TEKNOLOGI PEMBUATAN ALAT DAN PERHIASAN DI GUA KIDANG, BLORA
}

\section{THE TECHNOLOGY OF TOOLS AND ORNAMENTS PRODUCTION AT GUA KIDANG, BLORA}

\author{
Indah Asikin Nurani \\ Balai Arkeologi D.I. Yogyakarta \\ anikardani@gmail.com
}

\begin{abstract}
Gua Kidang is a prehistoric settlement that provides a complete description on the life pattern and the development of technology, as well as the adaptation strategy of the dwellers to survive. The development of technology was supported by the intelligence of the artist and the raw material provided in its neighbourhood. The manufacturing technique of tools and jewellery, found in Gua Kidang, demonstrated the effectivity aspect and unique innovation. Artifacts made from clamshell and bone, along with dental remains provide the insight on the variety of tools type and advance manufacturing technique compared to the type found in other prehistoric cave dwelling in Java as well asIndonesial. Based on the analysis of the manufacturing technique and geoarchaeological aspect, the cultural character of Gua Kidang's dwellers was shown through the development of technology. This paper uses descriptive methods - explanatory with inductive reasoning.
\end{abstract}

Keyword: Gua Kidang, Technology, Bone, Shell, Raw Material.

\begin{abstract}
ABSTRAK
GuaKidang merupakan hunian prasejarah yang memberikan gambaran secara lengkap pola hidup dan pengembangan teknologi, serta pola adaptasi manusia dalam mempertahankan hidupnya. Pengembangan teknologi, didasarkan pada kecerdasan artisan pembuatnya, serta bahan baku yang tersedia di lingkungan alam sekitarnya. Teknik pengerjaan alat dan perhiasan temuan di Gua Kidang, menunjukkan adanya aspek efektivitas dan inovasi tersendiri. Selain itu, temuan artefak kerang dan tulang, serta gigi memberikan kontribusi pengetahuan tentang ragam tipe alat dan teknik pengerjaan yang tinggi dibandingkan tipe alat temuan dari gua-gua hunian prasejarah di Jawa khususnya, dan Indonesia umumnya. Berdasarkan kajian teknik pembuatan dan aspek geoarkeologi, menunjukkan karakter budaya penghuni Gua Kidang dalam pengembangan teknologi. Tulisan ini menggunakan metode deskriptif - eksplanatif dengan penalaran induktif.
\end{abstract}

Kata Kunci: Gua Kidang, Teknologi, Tulang, Kerang, Bahan Baku.

Tanggal masuk : 2 Oktober 2015

Tanggal diterima : 31Mei 2016 


\section{PENDAHULUAN}

Blora merupakan salah satu

wilayah penting yang memiliki potensi arkeologis berupa tinggalan budaya sejak kala Plestosen, terutama di daerah DAS Bengawan Solo. Situs-situs Plestosen di daerah ini antara lain situs Mulyorejo, Jigar, Ngandong, dan Medalem. Balai Arkeologi Yogyakarta telah melakukan penelitian situs-situs Plestosen DAS Bengawan Solo daerah Blora ini sejak tahun 1977 dan berhasil mengumpulkan temuan fosil binatang purba seperti Stegodon, Elephas, rusa, kura-kura, sapi, dan kerbau. Data tersebut ditemukan satu konteks dengan tinggalan budaya alat tulang dan tanduk, serta alat dari cangkang kerang (Moeljadi, 1984).

Beberapa puluh tahun kemudian, saat penelitian tentang pola okupasi gua kawasan karst Blora tahun 2005, Dinas Kebudayaan dan Pariwisata Kabupaten Blora meminta Balai Arkeologi Yogyakarta untuk menginventarisasi potensi arkeologis di seluruh Kabupaten Blora. Permintaan tersebut ditindak lanjuti dengan melakukan penelitian pada tahun 2006 - 2007 di situs manusia purba di DAS Bengawan Solo yaitu Situs Kuwung, yang secara administratif terletak di Kecamatan Kradenan. Hasil survei di situs tersebut berupa sebaran fosil vertebrata dari jenis hewan gajah purba (Elephantidae dan Stegodontidae), banteng (Bos bubalus sp), kerbau (Bubalus palaeokarabau), rusa (Cervidae) babi (Suidae), kura-kura (Testudinidae, Chelonidae), badak (Rhinoceros sp.), kuda nil, serta fosil binatang air seperti ikan hiu dan kerang (Pelecypodae). Beberapa artefak seperti alat batu, alat tulang, dan alat tanduk juga ditemukan dalam penelitian tersebut. Temuan alat batu di situs tersebutantara lainadalah: kapak perimbas, kapak penetak, batu inti, alat serpih, alat bilah, dan serut, sedangkan temuan alat tulang adalah dua lancipan dari tulang dan satu alat dari tanduk. Sebagian besar fosil dan artefak yang ditemukan dalam survei tersebut sudah ada di permukaan tanah sebagaihasil dari penggalian liar yang dilakukan oleh penduduk sekitar situs. Sehubungan dengan hal tersebut, maka pertanggalan mutlak dari fosil-fosil tersebut tidak dapat diketahui dengan pasti, namun berdasarkan data geologi, diketahui bahwa temuan fosil berada pada formasi Kabuh pada endapan teras yang berumur Plestosen Tengah - Plestosen Atas (Hidayat, 2007).

Analisisidentifikasi temuan alat, menunjukan bahwa alat-alat yang ditemukan di Situs Kuwung merupakan hasil budaya fase Paleolitik yang dihasilkan oleh Homo erectus pada kala Plestosen. Identifikasi alat tanduk menunjukkan bahwa alat tersebut memiliki teknologi yang sama dengan alat tanduk yang ditemukan di situs Ngandong, sehingga diduga alat tersebut merupakan hasil budaya dari Homo erectus progresif yang berumur Plestosen Atas. Analisis temuan fosil stegodon sp. menunjukkan bahwa situs prasejarah di Kabupaten Blora memiliki potensi temuan fosil yang hidup pada kala Plestosen Tengah yang masuk pada kategori fauna Trinil (Hidayat, 2007). Terlepas dari temuan tersebut, sebagaimana disebut di atas, fokus penelitianawal adalahpola okupasi gua kawasan karst Blora, kehidupan kala Plestosen Atas sampai Awal Holosen. 
Kebudayaan manusia kala tersebut, telah meningkat sesuai dengan berkembangnya kecerdasan manusia saat itu. Mereka hidup secara semi nomaden atau berpindah-pindah dan mengumpulkanmakanan tingkat lanjut dengan mengembangkan teknologi mesolitik (Soejono, 2000). Pola hidup mereka tetapsama dengan masa sebelumnya yang tetap mengandalkan ketersediaan sumber makanan dan sumber bahan baku untuk peralatan sehari-hari yang tersedia di lingkungan alam sekitarnya. Manusia pendukung budaya tersebut mulai menempati gua atau ceruk sebagai tempat tinggalnya. Akan tetapi, berdasarkan survei terhadap seluruh kawasan karst Blora, diketahui bahwa sebagian besar gua dan ceruk yang ada, tidak layak huni. Hal tersebut, karena morfologi dan temuan permukaan gua dan ceruk tidak memberikan indikasi hunian. Jenis gua yang ada adalah jenis gua vertikal, sungai bawah tanah, dan rekahan bukit yang tidak layak huni. Satu-satunya gua yang secara arkeologis potensial dan layak huni, baruGua Kidangyang terletak di Desa Tinapan, Kecamatan Todanan, Kabupaten Blora (Nurani dan Susetyo, 2008). Selanjutnya disebut kawasan karst Todanan.

Pembentukan Gua Kidang memakan waktu yang lama. Pada awalnya merupakan aliran sungai bawah permukaan, selanjutnya mengalami pengeringan dan tidak berfungsi lagi, sehingga dasar gua tertutup oleh endapan agregat tanah. Material agregat berukuran butir pasir halus sampai lanau mengendap bersama air permukaan dan run off yang masuk ke dalam gua. Selain itu, proses sedimentasi juga terbentuk oleh media angin. Lahan gua dalam kondisi kering dengan intensitas sinar matahari masuk sekitar $30 \%$ membuat gua layak dan nyaman untuk digunakan sebagai tempat tinggal. Ukuran ruangan yang cukup luas dengan ketinggian atap gua kurang lebih 18 meter menambah kenyamanan pemanfaatan lahan gua dalam melakukan aktivitas sehari-hari (Nurani dan Hascaryo, 2011).

Temuan arkeologis di Gua Kidang, antara lain berupa cangkang kerang Pelecypoda, Gastropoda, tulang dan gigi binatang, fragmen tembikar, rangka manusia, dan batu. Bukti tinggalan tersebutpenting untuk mengungkapkan aspek-aspek sosio-budaya dan tingkat kepiawaian artisan dalam mengenal teknologi yang mereka miliki sebagai kesatuan ekosistem masa itu. Kerang Pelecypoda dan Gastropoda adalah bukti konsumsi manusia prasejarah pendukung Gua Kidang. Kerang atau moluskatampaknya tidak hanya diperoleh dari sungai dan rawa sekitar gua, namun keberadaan beberapa cangkang menunjukkan adanya eksplorasi lebih jauh yaitu di laut. Jarak antara gua dengan pantai terdekat yang terletak di sebelah utara gua kurang lebih $40 \mathrm{~km}$. Jarak tersebut merupakan hal yang memungkinkan dijangkau dalam jelajah manusia kala itu. Pola hidup yang masih semi menetapmemungkinkan jelajah sejauh itu, dalam mencari ketersediaan sumber makanan. Mereka akan menyiasati ketersediaan sumber makanan pada musim tertentu yang menyediakan flora dan fauna pada daerah tertentu (Doran, 1999). Selain itu, temuan tulang dan gigi binatang vertebratadari yang berukuran kecil seperti binatang Aves (unggas), Cervidae (kijang) hingga binatang berukuran besar seperti Bovidae menunjukkan intensitas eksplorasi 
manusia terhadap alam yang sangat tinggi pada saat itu (Nurani dan Hascaryo, 2011).

Sisa-sisa makanan, baik berupa cangkang kerang maupun tulang menunjukkan bahwa sisa-sisa itu tidak begitu saja dibuang sebagai sampah, namun dengan teknologi yang dimiliki, mereka mampu mengolah limbah menjadi peralatan sehari-hari. Peralatan sehari-hari manusia pendukung Gua Kidang, antara lain berupa lancipan tulang, lancipan kerang, serut tulang, gurdi tulang, gergaji kerang, dan perhiasan kerang dan tulang. Hal ini menunjukkan, bahwa mereka mampu beradaptasi pada lingkungan alam sekitar, sehingga menghasilkan peralatan yang mereka butuhkan dengan menggunakan teknik pengupaman serta pengasahan alat. Hal tersebut membuktikan, tingkat kecerdasan manusia saat itu dalam mengeksploitasi alam. Perapian merupakan prasarana yang menonjol dalam kehidupan di dalam gua, selain digunakan sebagai penghangat ruangan, memasak, juga menjadi bagian dari proses teknik pembuatan alat (Nurani, Hascaryo, dan Koesbardiati, 2012). Hal yang tidak berkembang di Gua Kidang adalah, alat batu. Hal ini tidak biasa terjadi pada budaya hunian gua, sehingga menjadi pertanyaan tersendiri.

Budaya hunian gua di Jawa khususnya, dikenal dengan sebutan "Budaya Sampung". Budaya Sampung dikenal dengan temuan khasnya berupa industri alat tulangterutama sudip (Tanudirjo, 1985). Menjadi hal yang menarik dipertanyakan, apakah seluruh hunian gua di Jawa satu periode dengan Budaya Sampung, ataukah Gua Kidang merupakan hunian gua sebelum budaya Sampung?Terlepas dari permasalahan tersebut, maka tulisan ini diharapkan memberikan kontribusi budaya hunian gua di Jawa dalam pengembangan teknologi pembuatan alat dan perhiasan.

Berdasarkan hasil penelitian di Gua Kidang dan didukung dengan berbagai temuan artefak baik dari kerang maupun tulang, serta batu, maka permasalahan yang akan dipecahkan dalam tulisan ini adalah sebagai berikut.

1. Bagaimana pola adaptasi manusia penghuni Gua Kidang dalam mempertahankan hidupnya? dan,

2. Bagaimana perkembangan teknologi pembuatan alat dan perhiasan?

\section{LANDASAN TEORI}

Kehidupan manusia penghuni gua masa prasejarah yang masih berpindah-pindah dalam mempertahankan hidupnya, dipengaruhi oleh potensi sumberdaya alam sekitarnya. Cara manusia mengeksplorasi dan mengeksploitasi alam sekitarnya, dipengaruhi kemampuan dan tingkat teknologi yang dikenalnya. Sebagai contoh adalah perkembangan pembuatan alat dengan alur perjalanan yang panjang. Alur perjalanan ituberkorelasi dengan tingkat kecerdasan manusia penggunanya dalam memanfaatkan sumberdaya alam. Berdasarkan hal tersebut, maka data teknomik merupakan hal yang mampu berbicara banyak, baik mengenai aspek teknik maupun tingkat kecerdasan manusia pendukungnya. Hal tersebut menunjukkan, bahwa hasil budaya merupakan adaptasi manusia terhadap lingkungannya, sebab dalam lingkungan alam yang 
berbeda, akan menghasilkan budaya yang berbeda pula.

Dalam teori sistem, kebudayaan merupakan suatu sistem yang terdiri atas beberapa subsistem yaitu subsistem teknologi, sosial, dan ideologi(James, 1977). Pembagian subsistem dalam kebudayaan tersebut, tidak dapat dipisahkan antara subsistem satu dengan subsistem lainnya. Haltersebut karena subsistemsubsistem saling berkaitan. Suatu subsistem dalam kesatuan suatu sistem harus bisa bekerja sama untuk menghasilkan sesuatu yang tidak dapat dibuat oleh masingmasing subsistem secara terpisah. Masuknya faktor luar ke dalam suatu sistem kebudayaan akan menyebabkan perubahanperubahan (James, 1977). Perubahan yang terjadi pada satu subsistem tidak langsung menimbulkan perubahan pada semua subsistem lain dalam waktu yang singkat. Perubahan yang terjadi pada lingkungan alam akan mengandung reaksi terutama dari subsistem teknologi, karena subsistem tersebut yang berhubungan langsung dengan flora-fauna dan geografis sekitarnya (Miksic, 1984). Perubahan oleh subsistem teknologi juga dapat terlihat pada jenis-jenis artefak teknomik. Oleh karena itu, dengan mengkaji dan menganalisis tentang artefak dan perubahan permukiman, dapat diungkap latar belakang perubahan pola hidup berpindahpindah.

\section{Prosesperkembangan}

teknologi pembuatan alat dan perhiasan, baik di Indonesia maupun di negara-negara lainnya, merupakan hal yang universal sama, khususnya perkembangan teknologi alat batu. Teknik pembuatan alatalat batu dari bentuk sederhana menuju bentuk yang lebih kompleks dan sempurna. Proses perkembangan tersebut, merupakan suatu proses evolusi teknologis yang cukup panjang dandikenal dengan istilah paleolitik (batu tua), mesolitik (batu madya), dan neolitik (batu muda). Peristilahan tersebut tidak menunjuk pada konotasi suatu periode (masa), tetapi hanya merupakan terminologi teknologis (Soejono, 2000).

Teknologi pembuatan alat, baik dari bahan baku apapun, pada dasarnya dilandasi oleh dua faktor, yaitu metode dan teknik. Metode berada pada bentuk fikiran, sedangkan teknik berada pada kedua belah tangan. Metode pembuatan alat, merupakan suatu tatanan yang dijalankan secara sistematis dan teratur dan bukan merupakan sesuatu yang terjadi secara kebetulan. Demikian pula halnya dengan ciri-ciri teknologis seperti dataran pukul (strikingplatform), bulbus (bulb of percussion), goresan bekas penyerpihan (bulbar scar), dan alur penyerpihan (ripples) merupakan akibat dari teknologi pembuatan yang diterapkan oleh si pembuat (Crabtree dalam Widianto, 1983).

Teknologi batu yang berkembang pada masa hunian di gua adalah teknologi mesolitik. Teknologi mesolitik setingkat lebih tinggi daripadateknologi paleolitik yang masih sederhana. Teknik pembuatan dan variasi produk pada teknologi mesolitik lebih cermat dibandingkan teknologi paleolitik. Peningkatan lebih lanjut dan cermat ditujukkan pada pangkasan dan menonjolnya penyerpihan kedua (secondary-retouched).

Produk teknologi pada tingkatan ini lebih bervariasi jenis alatnya, seperti tipe serpih, bilah, dan serut. Tipe lain yang muncul 
adalah lancipan-lancipan mikrolit dan mata panah sederhana. Secarateknologis, ciri kuat yang tampak adalah adanyabulbus-bulbus negatif pada bagian dorsal, bagian ventral tanpa faset, dan adanya dataran pukul. Selain ciri-ciri teknologis tersebut, hal yang khas pada teknik mesolitik adalah penggunaan teknik penghalusan melalui pemangkasan kedua (secondary retouched), untuk membentuk tajaman.

Berbeda halnya dengan teknologi alat tulang dan kerang. Sebagian besar alat dan perhiasan yang dihasil kurang bervariasi, sedangkan pengerjaannya lebih pada pangkas dan upam. Alat atau perhiasan dari tulang, biasanya memilih bahan dari bagian tulang panjang, salah satu atau dua bagian dipangkas untuk membuat tajaman. Selanjutnya diupam atau digosok sampai mengkilap (Webb, 1990). Adapun teknik pembuatan alat atau perhiasan dari cangkang kerang, lebih sederhana lagi dibandingkan alat dari tulang. Hal tersebut dikarenakan bahan cangkang kerang merupakan sutura-sutura yang memiliki alur-alur yang mudah dipangkas membentuk tajaman. Pangkasan dalam alat kerang, meliputi serpihan mikro (microfracturing), striasi (striations), dan garis-garis lurus (linear features), kilapan (polish), lubanglubang kecil akibat hantaman (impact pits), serta penumpulan (edge rounding) (Oakley, 1959).

\section{METODE PENELITIAN}

Berdasarkan pemahaman
teori sistem dan teknologi
pembuatan alat sebagaimana
diuraikan di atas, maka metode
penelitian dalam tulisan ini
menggunakan penalaran induktif

dengan tipe deskriptif-eksplanatif. Pengamatan teknologi didasarkan pada teknik pengerjaan dan pangkasan dengan membandingkan temuan artefak dari situs gua lainnya khususnya di Jawa. Tidak seluruh temuan dibahas dalam tulisan ini, namun hanya beberapa sampel yang signifikan, terutama dari aspek teknik pengerjaan dan fungsi. Posisi temuan kaitannya dengan lapisan tanah juga dideskripsi, untuk menjajagi dinamika teknologi alat. Selain itu, dilakukan juga pengamatan geologis sehubungan dengan keberadaan sumber bahan baku.

Diharapkan metode tersebut dapat memecahkan masalah yang telah dirumuskan. Bagaimana pola adaptasi yang diterapkan dengan alam lingkungan sekitarnya melalui kajian geologis. Selanjutnya akan terjawab mengapa penerapan teknologi tertentu yang digunakan berdasarkan ketersediaan bahan baku yang ada.

\section{TEMUAN ARTEFAK KERANG DAN TULANG GUA KIDANG}

Gua Kidang, terletak di Desa Tinapan, Kecamatan Todanan, Kabupaten Blora. Merupakan gua di bawah permukaan tanah sekitar, atau disebut dolina. Luas dolina Kidang cukup luas, terdiri atas dua gua yaitu Gua Kidang $A$ dan Gua Kidang AA. Luas Gua Kidang A adalah $36 \mathrm{~m} \times 18 \mathrm{~m} \times 18 \mathrm{~m}$. Sedangkan Gua Kidang AA merupakan ceruk yang melebar mengikuti dinding dolina. Ekskavasi dilakukan pada beberapa kotak gali berukuran $1,5 \mathrm{~m} \times 1,5 \mathrm{~m}$ dengan membuat grid pada seluruh lahan dolina. Pemilihan kotak ditentukan pada bagian depan, belakang (dalam), tengah bagian kiri, dan tengah bagian kanan. Lebih lanjut 
dapat dilihat gambar denah Gua Kidang berikut:

Temuan artefak baik itu peralatan maupun perhiasan Gua Kidang, didominasi oleh bahan cangkang kerang dan tulang. Jumlah artefak bahan batu sangat sedikit. Hal tersebut, didasarkan kajian geoarkeologi melalui survei dan pelacakan temuan ekskavasi menunjukkan, bahwa bahan baku batu dengan kandungan silikaan tinggi tidak ada di sekitar kawasan karst Todanan. Lokasi terdekat $( \pm 10$ $\mathrm{km}$ ) sumber bahan baku batu dengan silikaan tinggi, berada di daerah Dumpil, Sungai Lusi,

\section{A. Artefak Batu}

Meskipun tidak menonjol, temuan artefak batu di Gua Kidang terdiri atasbatu pukul dan alat pengasah alat kerang dan tulang atau disebut batu asah. Temuan batu pukul ditemukan di semua kotak gali dari bahan batu andhesit, batugamping, dan beberapa dari batu gamping silikaan yang memiliki kekerasan di bawah 5 mohs. Jejak-jejak pemakaian tampak sangat intentif yang ditunjukkan denganterkelupasnya korteks batu pada berbagai sisi. Indikasi batuasah adalah jejak guratan horisontal pada permukaan batu,

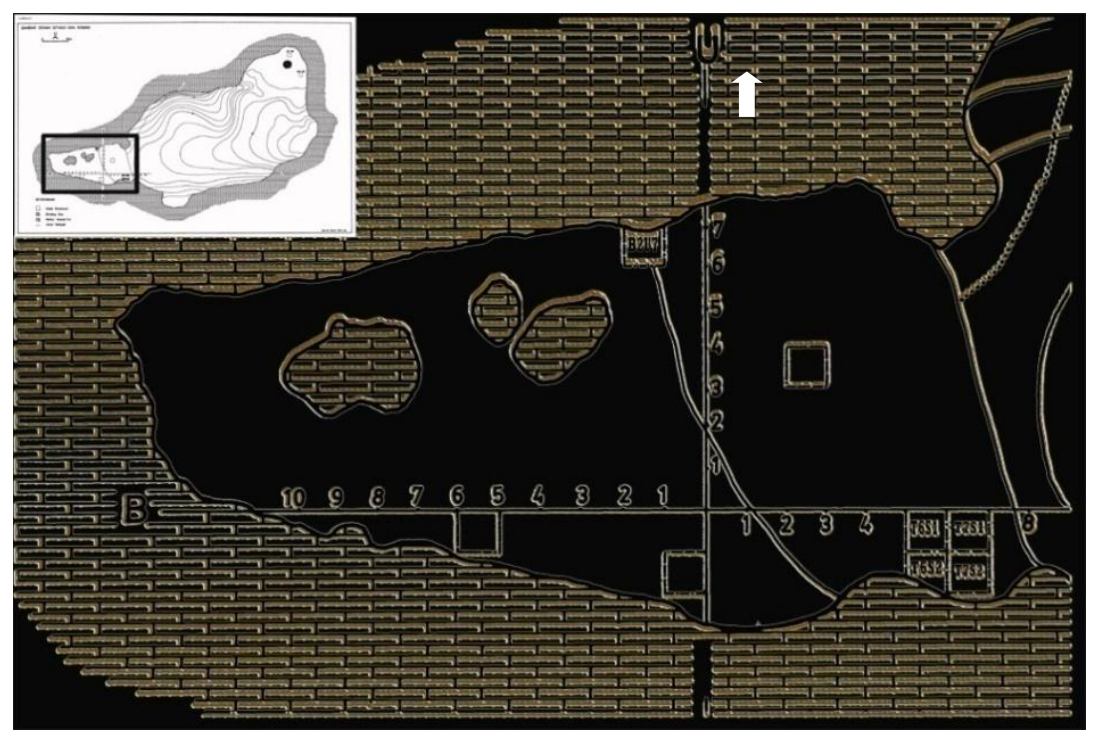

Gambar 1. Denah Gua Kidang A (Sumber: Nurani, 2015)

Kabupaten Grobogan dengan aliran anak-anak sungai di Kecamatan Kunduran, Kabupaten Blora, serta lokasi terjauh di DAS Bengawan Solo $( \pm 40 \mathrm{~km}$ ) yang terletak di Kecamatan Kradenan, Kabupaten Blora (Nurani dan Hascaryo, 2011).

Berikut temuan artefak baik alat maupun perhiasan temuan ekskavasi Gua Kidang dari batu, kerang dan tulang, serta gigi (Nurani, 2009; 2010; 2011; Nurani, Hascaryo, Koesbardiati, 2012; 2014; 2015). sehingga membentuk goresan pada batu tersebut. Dugaan sementara batu asah ini digunakan untuk mempertajam alat dari cangkang kerang dan alat dari tulang dengan cara seperti meraut. Bahan yang digunakan sebagian besar adalah batu rijang merah dan kuning berukuran krakal dengan tingkat kekerasan skala mohs antara 5-7. Temuan batu asah ini ditemukan pada semua kotak gali.

Berdasarkan temuan artefak batu tersebut, menunjukkan bahwa alat dari batu bukan merupakan alat 
utama, namun sebagai alat pendukung. Menjadipertanyaan, dari mana bahan-bahan batuan yang tidak terdapat di lingkungan sekitar gua, diperoleh? Mengingat bahan bakubatu rijang tersebut tidak terdapat di sekitar gua. Kajian geologis menunjukkan sumber bahanbaku batu tersebut terdapat di sekitar daerah aliran sungai Bengawan Solo (berjarak sekitar 40 $\mathrm{km})$. Jarak sejauh itu, merupakan hal yang biasapada pola hidup manusia kala yang masih semi

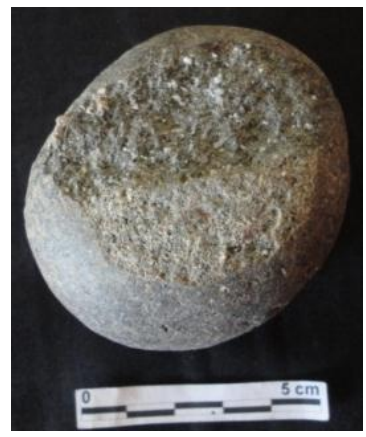

Gambar 2. Batu pukul dari batu andesit (Sumber: Nurani, Hacaryo, 2011)

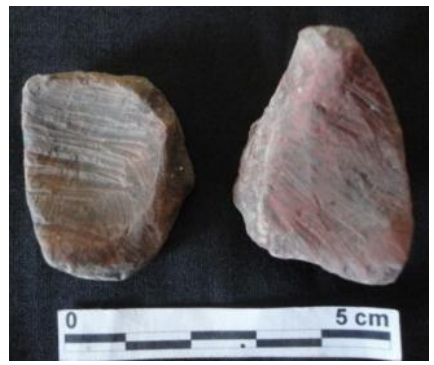

Gambar 3. Batu Asah dari batu rijang (Sumber: Nurani, Hacaryo, 2011) menetap.

\section{B. Kerang-Tulang Berlubang}

Dalam hal ini yang dimaksud kerang atau tulang berlubang adalah perhiasan. Pembuatan lubang dilakukan dengan teknik bor. Penggunaan bor diketahui berdasarkan pada ukuran cangkang bagian atas yang lebih lebar diameternya, dibandingkan bagian bawah. Beberapa temuan lain menunjukkan, bahwa pembuatan lubang selain sebagai perhiasan seperti liontin, anting-anting, juga dimaksudkan sebagai tempat mengaitkan seutas tali.

Hal yang perlu diketahui, terdapat dua jenis artefak yang berlubang. Apabila artefak berlubang tersebut, di bagian lainnya baik itu di atas atau di samping dikerjakan lebih detail untuk tajaman, maka fungsi dari artefak tersebut bukan sebagai perhiasan, namun merupakan alat seperti serut atau sudip. Berikut beberapa temuan kerang dan tulang (gigi) berlubangbaik sebagai perhiasan maupun alat (periksa lampiran tabel temuan artefak Gua Kidang).

Artefakkerang dan tulang, serta gigi yang sengaja dibuat lubangselain berbentuk lingkaran, jugaberbentuk bunga. Apakah artefak ini merupakan manik-manik atau bukan, belum dapat dipastikan mengingat apabila disebut manikmanik, maka tentunya temuan artefak berlubangini berjumlah banyak. Hal tersebut karena pengertian manik-manik berkonotasi dengan untaian/rangkaian dari manik-manik untuk dibuat gelang atau kalung. Untuk itu, dalam hal ini disebut sebagai perhiasan.

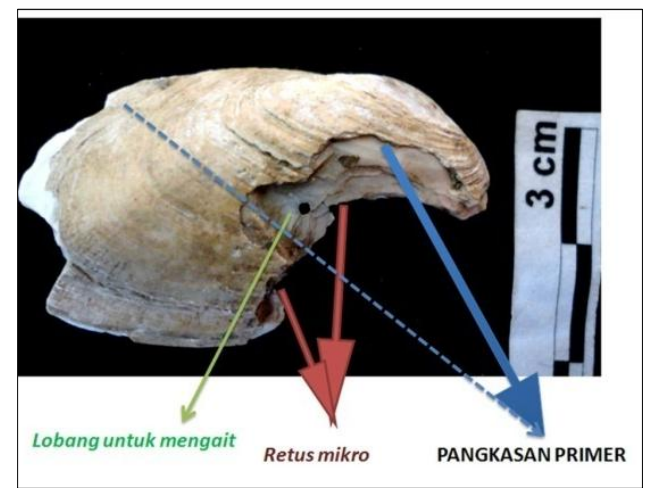

Gambar 4. Serut Cekung berlubang (Sumber: Nurani, Hacaryo, 2011) 
Berikut posisi temuan diurutkan berdasarkan kedalaman dari permukaan tanah. Temuanartefak berlubang paling dangkal ditemukan pada kedalaman $40-50 \mathrm{~cm}$ dari permukaan tanah sampai pada kedalaman $157 \mathrm{~cm}$ dari permukaan tanah. Pada kedalaman $40-50 \mathrm{~cm}$, temuan dari kotak T6S1, ukuran 5,2 x 2,4 × 0,2 $\mathrm{cm}$ berupa perhiasan darikerang berlubang menyerupai bunga. Selanjutnya pada kedalaman yang sama dari kotak U31T49 adalah alat berupa serut yang diberi lubang, sebanyak dua buah. Specimen pertama ukuran alat $4 \times 3,1 \mathrm{~cm}$, tampak pengerjaan dengan pangkasan cekung berukuran mikro pada lateral kiri, bagian bonggol dibuat kaitan seperti paruh burung. Specimenkedua dengan ukuran 3,6 $x 2,2 \mathrm{~cm}$, cekungan dibuat pada lateral kiri. Pada bagian bonggol dilubangi bentuk segitiga, selanjutnya dipangkasserong ke arah bawah.

Temuan lainnya adalah pada kedalaman $47 \mathrm{~cm}$ dari permukaan tanah, berupa kerang berlubangdengan ukuran 5,3 × 3 x $0,2 \mathrm{~cm}$ terbuat dari cangkang kerang pelecypoda utuh. Pengerjaan dilakukan pada bagian lateral kanan dengan membentuk cekungan dan di bagian tengah dibuat lubang besar berdiameter $1,3 \mathrm{~cm}$.

Pada kedalaman $99 \mathrm{~cm}$ dari permukaan tanah ditemukan serut yang dilubangi, ukuran 5,3 x 2,6 x $0,3 \mathrm{~cm}$. Cangkang kerang utuh bagian kiri dikerjakan dengan pangkasancekung berukuran makro tiga buah. Pada lateral kiri bawah dilubangi. Kemungkinan artefak ini memiliki fungsi ganda, selain sebagai perhiasan juga sebagai alat (lihat gambar 4).

Pada kedalaman 115 - 120

$\mathrm{cm}$ dari permukaan tanah, ditemukan serutbergerigi yang dilubangi dengan pengerjaan yang intensif. Artefak inididugaberfungsi ganda bukan sebagai perhiasan saja, tetapi juga berfungsi sebagai alat. Ukuran dari temuan tersebut adalah4,9 $\times 2,8 \times 0,5 \mathrm{~cm}$. Diameter lubang1,2 $\mathrm{cm}$ pada bagian tengah cangkang. Sementara pada bagian bawah dikerjakan dengan teknik pengerjaan retus untuk membentuk tajaman runcing secara mikro seperti gergaji (lihat gambar 5).

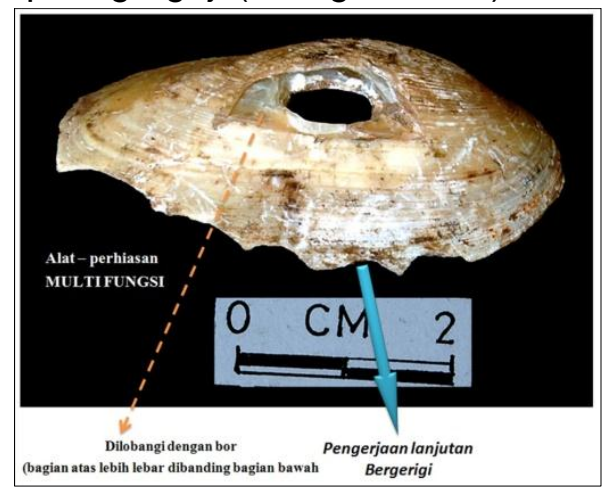

Gambar 5. Serut Bergerigi berlubang

(Sumber: Nurani, Hacaryo, 2011)

Temuan lainnya yang tak kalah penting adalah temuan pada kedalaman $122 \mathrm{~cm}$ dari permukaan tanah berupa gigi canineCanidae yang diberi lubang pada bagian akar gigi. Tanda kalau artefak ini merupakan perhiasan adalah dibuatnya lubangpada bagian akar gigi dengan diameter $0,2 \mathrm{~cm}$ dengan cara melubangi akar gigi yang telah dipangkas terlebih dahulu agar pipih. Bagian gigi yang sudah berbentuk runcing, dibiarkan utuh. Ukuran perhiasan adalah $2 \times 0,6 \mathrm{~cm}$. Berdasarkan bentuknya, artefak ini merupakan anting-anting atau liontin.

Artefak tulang berlubang juga ditemukan pada kedalaman $150 \mathrm{~cm}$ dari permukaan tanah. Merupakan cranium binatang yang dilubangi dengan diameter $0,4 \mathrm{~cm}$, ukuran 3,9 $x 3 \times 0,7 \mathrm{~cm}$. Kemungkinan artefak ini merupakan perhiasan. Selain itu, 
temuan dari kedalaman $157 \mathrm{~cm}$ dari permukaan tanah berupa artefakmulti fungsi, selain sebagai perhiasan juga merupakan serut. Cangkang ini tampak terbakar. Terbuat dari cangkang kerang Pelecypoda, ukuran 3,7 × 2,1 x 0,5 $\mathrm{cm}$. Pengerjaan secara intensif dan tampak adanya pemakaian yang intensif juga. Cangkang bagian atas atau terkeras dibiarkan utuh tanpa pengerjaan. Pengerjaandilakukan pada lateral kanan dan kiri, serta bagian bawah. Bagian tengah cangkang dilubangi serta tampak ada usaha membuat lubanglagi, tapi tidak berhasil. Pengerjaan pada bagian lateral baik kanan maupun kiri dilakukan dengan pangkasan mikro meruncing yang selanjutnya dikerjakan lagi dengan retus secara mikro.

Berdasarkan temuan kerang dan tulang berlubang di atas, hal yang menarik adalah tahap penggunaan, terutama untuk jenis artefak multi fungsi. Kemungkinan pada awalnya artefak berlubang sengaja dibuat untuk perhiasan? Ataukah pembuatan lubang tersebut dibuat setelah artefak tersebut digunakan sebagai alat? Apabila dugaan pertama yang benar, maka pangkasan yang dikerjakan untuk membuat tajaman merupakan alih fungsi artefak. Dalam hal ini dari perhiasan menjadi alat. Selanjutnya apabila dugaan kedua yang benar, maka pembuatan lubang dikerjakan untuk segi praktis yakni dijadikan gantungan untuk mengaitkan tali.

Selain itu, berdasarkan posisi temuan menunjukkan adanya dinamika teknologi artefak dengan lubang. Temuan artefak baik cangkang kerang, tulang maupun gigi pada lapisan atas cenderung sebagai perhiasan, sedangkan temuan pada lapisan bawah merupakan lubang yang dibuat untuk kebutuhan praktis. Kebutuhan praktis dimaksud adalah utamanya artefak tersebut merupakan alat seperti serut yang dibuat lubang untuk dikaitkan dengan tali.

\section{Hiasan}

Temuan pada kedalaman 20

$\mathrm{cm}$ dari permukaan tanahdari cangkang Gastropoda sub classOpisthobranchia, ukuran 3,1 x $2,4 \mathrm{~cm}$ diduga merupakan hiasan. Meskipun dari fungsi masih dipertanyakan, apakah sebagai hiasan saja, ataukah sebagai alat. Dugaan sebagai hiasan, karena berbentuk seperti kelopak bunga, sedangkan dugaan sebagai alat adalah jenis lancipan. Pengamatan lebih lanjut terhadap artefak ini masih diperlukan. Cangkang merupakan ruas satu bagian atas, pangkasan dilakukan secara zig-zag yang selanjutnya diretus runcing menyudut, sehingga membentuk tiga lancipan. Bagian batas ruas dan mulut cangkang dibiarkan tanpa pengerjaan.

\section{Serut Lancipan}

Serut - lancipan merupakan alat multi fungsi yang digunakan lebih dari satu fungsi. Alat ini ditemukan pada kedalaman $0-40$ $\mathrm{cm}$ dari permukaan tanah. Pangkasan dilakukan pada bagian

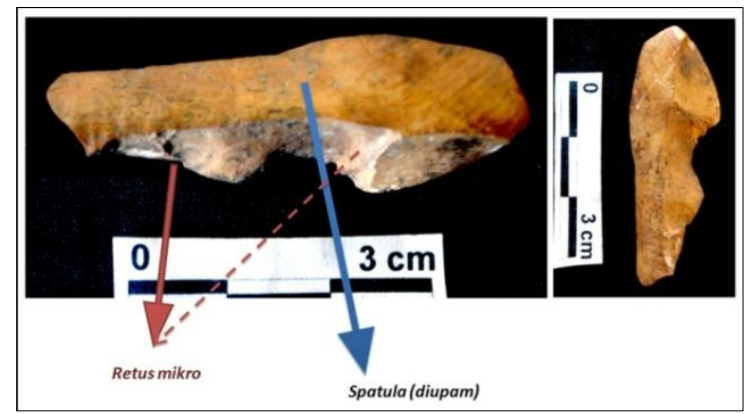

Gambar 6. Bilah dari Tulang, pengerjaan teknik alat batu (Sumber: Nurani, Hacaryo, 2011)

lateral kiri pada bagian atas dibuat runcing sementara bagian 
bawahnya diretus mikro dan tampak adanya jejak pemakaian. Bagian lainnya dibiarkan utuh tanpa pengerjaan. Temuan lainnya berukuran 4,5 x 3,2 cm memiliki ciri yang sama, perbedaannya pangkasan dilakukan pada seluruh bagian secara longitudinal, sedangkan runcingan hanya sebuah yaitu pada bagian atas lateral kiri.

\section{E. Serpih - Bilah Tulang}

Keistimewaan temuan dari Gua Kidang adalah artefak dari tulang dan cangkang kerang yang dibuat dengan teknik pengerjaan alat batu. Beberapa indikasi penerapan teknologi alat batu tampak jelas baik dalam teknik pengerjaan seperti teknik pelepasan dari inti bahan, dataran pukul, bulbus, retus, serta pangkasan pada bagian dorsal dan ventral. Beberapa temuan dengan indikasi teknik pengerjaan tersebut antara lain sebagai berikut.

Temuan pada kedalaman 40 $\mathrm{cm}$ dari permukaan tanah, merupakan spatula yang dikerjakan lagi. Specimen ini menunjukkan bahwa awalnya merupakan spatula, selanjutnya dikerjakan lagi, sehingga menjadi bilah. Tampaknya spatula ini dalam pengerjaannya telah sempurna, terlihat dari pengupaman dengan hasil yang halus dan licin permukaannya. Pembuatan bilah dengan ciri ukuran panjang minimal 2 kali ukuran lebar menunjukkan teknik pengerjaan alat litik. Setelah pangkasan yang dipersiapkan dari spatula, dengan ukuran 4,2 x 1,6 $\mathrm{cm}$, selanjutnya diretus mikro bergerigi pada satu sisinya (lateral kanan), sehingga bagian tersebut pipih dan tajam (lihat gambar 6).

Temuan-temuan lain, berupa serut dari tulang yang menerapkan teknik pengerjaan alat batu juga ditemukan pada kedalaman $72 \mathrm{~cm}$ dari permukaan tanah, kondisi tulang terbakar dengan ukuran 5,2 $\mathrm{x}$ 2,9 cm. Teknik pangkas sebagaimana yang diterapkan pada pembuatan alat batutampak jelas pada alat tulang ini, yaitu adanya dataran pukul. Selain itu, bagian ventral dan dorsal hanya dipangkas

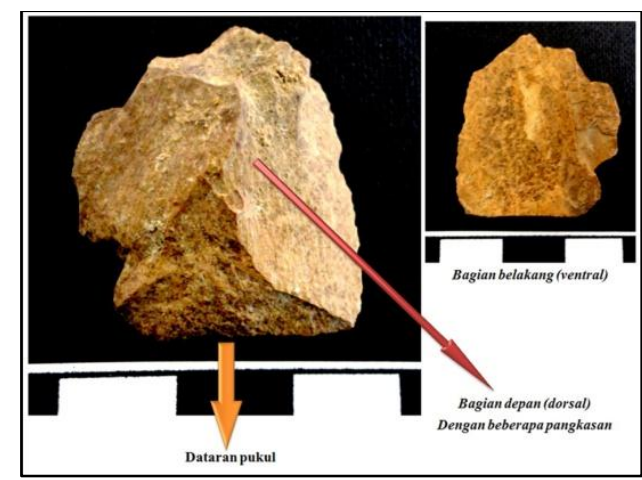

Gambar 8. Serpih dari Tulang, pengerjaan teknik alat batu (Sumber: Nurani, Hacaryo, 2011)

bagian atas saja, sehingga membentuk lancipan.

Temuan lainnya dengan teknik pengerjaan alat batu adalah temuan pada kedalaman 110-120 $\mathrm{cm}$ dari permukaan tanah berupa serpih dan bor. Serpih, dengan ukuran 2,7 x 1,3 x 0,7 cm, teknik pangkasan menerapkan teknologi alat batu, diidentifikasikan dengan adanya dataran pukul, dan pangkasan pada bagian dorsal dan ventral. Pada bagian dorsal, pangkasan dua sisi kiri - kanan, sehingga bagian tengah menyudut. Bagian ventral dipangkas pada beberapa arah. Adapun bor dengan ukuran 3,1 x 1,2 × $1 \mathrm{~cm}$, dari tulang. Tampak bor dari tulang bagian lekukan atau kanal tulang (tempat sumsum). Salah satu bagian dibuat pipih dan dipangkas cekung membentuk paruh burung dengan ujung runcing. Kondisi tulang terkonkresi (berlapis batu kapur) tingkat lanjut (lihat gambar 7). 


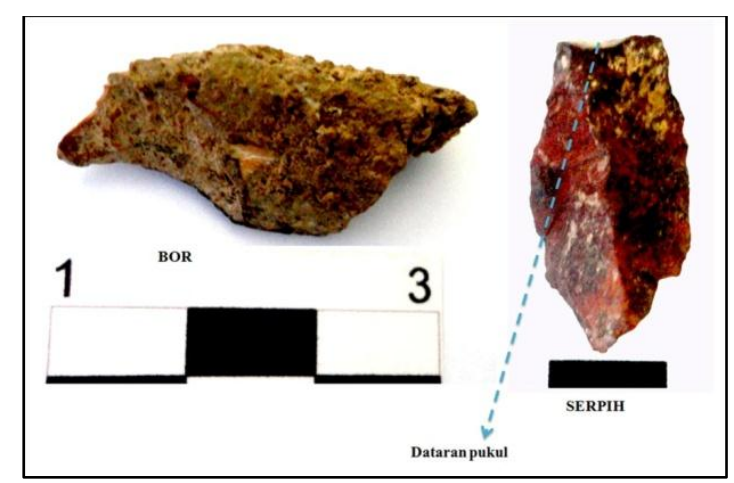

Gambar 7. Bor dan Serpih dari Tulang, pengerjaan teknik alat batu (Sumber: Nurani, Hacaryo, 2015)

Temuan lainnya pada kedalaman 110 - $120 \mathrm{~cm}$ dari permukaan tanah, berupa serpih dengan ukuran alat 2,9 $\times 2,1 \mathrm{~cm}$. Teknik pengerjaan alat batu yang tampak jelas pada serpih tulang ini, adalah adanya dataran pukul, bagian ventral, bagian dorsal, dan pangkasan-pangkasan bagian dorsal (lihat gambar 8).

\section{F. Serut Samping, Serut Cekung, Serut Bertangkai Dari Cangkang Kerang}

Pengerjaan dengan teknik pengerjaan alat batu juga diterapkan pada alat dari cangkang kerang. Alat kerang jenis serut memiliki tipe alat yang beragam. Penamaan didasarkan dominasi bagian untuk dibuat tajaman, sehingga jenis alat menjadi serut samping karena pembuatan tajaman hanya dikerjakan pada satu bagian samping saja. Serut cekung, pangkasan utama sengaja dibuat cekung, selanjutnya dilakukan pangkasan sekunder yaitu retus untuk mempertajam alat. Adapun serut tipe bertangkai adalah, serut yang bagian pangkalnya dikerjakan bentuk tangkai. Pengerjaan tangkai dilakukan dengan pangkasanpangkasan sekunder dengan lebar lebih sempit dari pada bagian alat. Maksud dibuatnya tangkai pada alat kemungkinan nantinya dikaitkan dengan tongkat atau tali. Berikut temuan jenis serut diurutkan berdasarkan posisi temuan dari lapisan atas ke bawah.

Temuan serut cekung dari cangkang kerang laut pada kedalaman $20-30 \mathrm{~cm}$ dari permukaan tanah, dengan ukuran ukuran alat adalah $3,3 \times 3,3 \mathrm{~cm}$. Pengerjaan dilakukan secara intensif pada bagian lateral kanan dan kiri, setelah dipangkas vertikal pada bagian tengah bidang cangkang. Lateral kanan dipangkas menyudut, sehingga menghasilkan bentuk cekungan dalam, selanjutnya diretus secara mikro. Bagian lateral kiri dikerjakan dengan pangkasan makro sebanyak 6 pangkasan, sehingga bergerigi (lihat gambar 9).

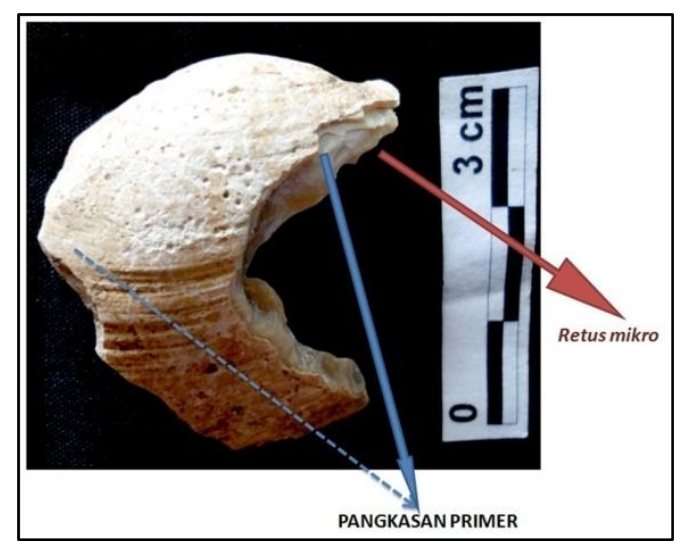

Gambar 9. Serut Cekung, pengerjaan teknik alat batu (Sumber: Nurani, Hacaryo, 2011)

Artefak serut lainnya adalah serut bertangkai. Serut berukuran $4,1 \times 2,3 \mathrm{~cm}$, dibuat seperti penjepit yaitu dipangkas menjorok ke dalam dengan pengerjaan pada bagian bonggol. Bagian lateral kiri serta lateral kanan dibiarkan utuh. Terdapat juga pembuatan tangkai pada lateral kanan. Ukuran artefak adalah 5,2 x 2,7 cm. Serut lain yang ditemukan, adalah serut berbentuk segitiga yang sisi-sisinya tampak jejak pemakaian. Ukuran artefak 4,3 $x 2,8 \mathrm{~cm}$. Serut ini tampak ada 
kesengajaan dipanggang untuk pengerasan, sehingga seluruh permukaan alat berwarna hitam. Diduga tangkai alat ini akan diikatkan dengan tali atau dipasang pada tongkat yang selanjutnya diikat tali. Dugaan tersebut perlu pengamatan lebih lanjut.

Serut samping dari cangkang mollusca laut, berukuran $6 \times 4,1 \mathrm{~cm}$. Pengerjaan pada lateral kanan dengan empat pangkasan makro serong dari lateral kanan ke bawah. Tampak jelas jejak-jejak pemakaian intensif yaitu adanya primping (Wahyuni, 2014). Temuan serut samping lainnya pada kedalaman yang sama, dengan ukuran 3,8 x 2,2 $\mathrm{cm}$. Pengerjaan pada satu bagian saja, yaitu pada lateral kanan (lihat gambar 10).

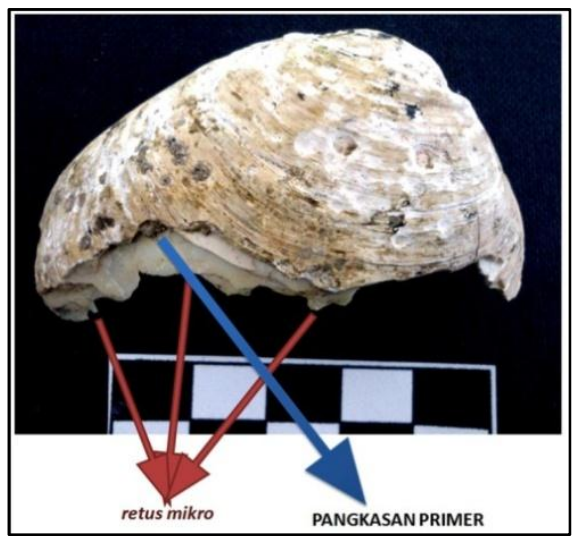

Gambar 10. Serut Samping, pengerjaan teknik alat batu (Sumber: Nurani, Hacaryo, 2011)

\section{G. Spatula}

Spatula mulai ditemukan pada kedalaman 40 - $50 \mathrm{~cm}$ dari permukaan tanah. Temuan spatula menarik untuk diungkap mengingat terdapat dinamika teknologi yang signifikan.

Lapisanbawah (kedalaman lebih dari $100 \mathrm{~cm}$ ) menunjukkan temuan spatulabelum sempurna atau calon spatula, meskipun tampak indikasi pengupaman, namun belum halus.
Indikasi awal pengerjaan spatula adalah lancipan dan sudip. Indikasi alat tersebut merupakan calon spatula, pengerjaan untuk membentuk tajaman seperti spatula, yakni pipih dan membundar. Selain itu juga ada beberapa bagian yang diupam. Selanjutnya, pada lapisan di atasnya, merupakanspatula dengan pengerjaan

sempurna.Seluruhpermukaan tulang diupam dengan tajaman pipih seperti sendok. Terakhir, temuan spatula pada lapisan atas, tampak spatula dikerjakan ulang, yang menghasilkan jenis alat yang berbeda, seperti sebagai bilah atau lancipan. Berikut temuan spatula dari lapisan atas sampai lapisan bawah.

Temuan spatula pada kedalaman $52 \mathrm{~cm}$ dari permukaan tanah, merupakan fragmen spatula yang patah pada bagian panjang, dengan ukuran alat $3,9 \times 2,9 \mathrm{~cm}$. Tampak jelas jejak pengupaman yang sempurna. Pada bagian tajaman tampak pemakaian yang intensif dengan indikasi berupa perimping. Bagian lekukan tulang hampir rata, akibat pengupaman. Fragmen spatula lainnya pada kedalaman $53 \mathrm{~cm}$ dari permukaan tanah, dengan ukuran spatula 6,2 $\mathrm{x}$ $9,2 \times 1,2 \mathrm{~cm}$. Spatulalainnya ditemukan pada kedalaman $65 \mathrm{~cm}$ dari permukaan tanah, dengan ukuran spatula $5,8 \times 2,7 \mathrm{~cm}$. Merupakan spatula dengan pengupaman yang dilakukan pada bagian tajaman dan tepian. Bagian lekukan tulang masih tampak jelas.

Temuan spatula pada kedalaman $66 \mathrm{~cm}$ dari permukaan tanah, merupakan spatula patah pada bagian kiri, dengan ukuran spatula7,1 x 2,4 cm. Pengupaman telah sempurna terutama pada bagian tajaman, namun bagian ventral masih tampak lekukan 
tulang. Pada kedalaman $67 \mathrm{~cm}$ dari permukaan tanah, temuan spatula dengan ukuran 6,2 x 2,7 cm, menunjukkan pangkasan dilakukan dengan membelah tulang serta melakukan pengupaman pada bagian tajaman. Bagian ventral datar, kemungkinan karena keropos.

Pada kedalaman $129 \mathrm{~cm}$ dari permukaan tanah, ditemukan calon spatula, dari tulang femur Bovidae, dengan ukuran alat: $5,7 \times 3 \times 0,9$ $\mathrm{cm}$. Spatula ini tampak belum sempurna pengerjaannya. Pada bagian permukaan tulang tampak jejak pengupaman yang belum sempurna berbentuk pipih. Bagian tajaman berupa lancipan, tampak adanya perimping jejak pemakaian. Pengerjaan dilakukan pada bagian atas (distal) danbagian bawah (proksimal). Bagian distal dipangkas membulat menyerupai sendok/sudip dan diupam, sementara pada bagian proksimal dipangkas membentuk dua lancipan, sehingga tampak zigzag.

Temuan calon spatula lainnya, adalah pada kedalaman 136 $\mathrm{cm}$ dari permukaan tanah, sejumlah dua buah. Specimen pertama berupa lancipan dan sebuah adalah bilah. Lancipan dari femur Gallidae dengan ukuran alat 4,3 $\times 1 \times 0,3 \mathrm{~cm}$. Pengerjaan tajaman dilakukan secara menyeluruh sehingga berbentuk segitiga. Bagiandistal meruncing, sedangkan bagian proksimal tumpul. Specimen kedua, bilah atau pisau dari tulang femur Cervidae, berukuran 4,8 x 1,7 x 0,7 $\mathrm{cm}$. Kemungkinan merupakan spatula yang belum sempurnapengerjaannya, sehingga tampak seperti lancipan. Kedua calon spatula ini menerapkan teknik pengerjaan alat batu, yaitu adanya dataran pukul dengan pangkasan longitudinal pada saat membelah tulang. Tampak jelas jejak pemakaian (primping) pada bagian distal (Suhari, 2014).

Selanjutnya temuan calon spatula berupa sudip atau belati pada kedalaman $138 \mathrm{~cm}$ dari permukaan tanah. Artefak ini dimasukkan dalam jenis calon spatula, didasarkan karena bagian tajaman yang pipih seperti sendok, serta adanya indikasi diupam. Sudip berbentuk seperti belati, dibuat dari fragmen tulang femur Cervidae, dengan ukuran $11,1 \times 2,4 \times 0,9 \mathrm{~cm}$. Bagian atas atau distal dipangkas kanan - kiri secara longitudinal. Bagian proksimalujung tajaman dipangkas menipis sampai bagian lekukan kanal tulang (sumsum) hilang. Alat ini kemungkinan disambung dengan tangkai sehingga dapat dijadikan tombak atau belati.

\section{PENGEMBANGAN TEKNOLOGI ALAT DAN PERHIASAN, DI GUA KIDANG}

Berdasarkan uraian bab-bab di atas, temuan artefak baik dari batu, kerang, maupun tulang serta gigi, menunjukkan artefak batu merupakan alat pendukung. Hal tersebut disebabkan bahan baku batu dengan silikaan tinggi seperti batu rijang yang merupakan jenis batuan yang digunakan membuat peralatan serpih-bilah dan serut, tidak tersedia di sekitar Gua Kidang dan kawasan karst Todanan. Selanjutnya, dengan bukti temuan artefak batu di Gua Kidang tersebut, apabila dikorelasikan dengan kenampakan slicent slide pada alat tulang dan kerang, terbukti bahwa manusia pendukung gua memiliki kekhususan dalam pemakaian batuan silica. Batuan tersebut tampaknya hanya sebagai bahan pendukung atau secondary materialpada peralatan dari tulang dan kerang, yaitu sebagai batu pukul 
dan batu asah. Hal ini berbeda dengan pengembangan teknologi manusia penghuni gua-gua prasejarah di Indonesia pada umumnya.

Berbeda halnya dengan temuan artefak dari tulang dan cangkang kerang, sebagaimana telah diuraikan di atas. Pengerjaan artefak dari kerang dan tulang baik sebagai alat maupun perhiasan, memiliki kekhasan tersendiri. Hal tersebutdisebabkan lingkungan alam berpengaruh besar terhadap hasil budaya. Berdasarkan kajian perkembangan teknologi, yang telah diuraikan di atas melalui posisi temuan (vertikal) dengan teknik pengerjaan artefak, maka dapat diterapkan konsep teknomik sebagaimana yang disampaikan Clarke (1977). Konsep yang didasarkan pada data teknomik, mencerminkan tingkat kecerdasan manusia pendukungnya dan adaptasi manusia terhadap lingkungannya. Beberapa hal penting yang dapat dirumuskan atas kajian teknologi temuan artefak dan kondisi lingkungan alam sekitar Gua Kidang adalah sebagai berikut. Manusia dari masa prasejarah kala Plestosen Atas sampai kala Holosen yang tinggal di gua, memiliki cara yang unik untuk mempertahankan hidupnya. Mereka memberdayakan potensi sumberdaya alam yang ada di sekitarnya dan itu berkembang di seluruh dunia. Sebagaimana telah dijelaskan di atas, bahwa teknologi yang diterapkan pada pembuatan alat dan perhiasan dari kerang, tulang, dan gigi, sebagian besar adalah teknologi batu. Hal ini jelas berbeda dengan produk artefak kerang dan tulang lainnya yang ditemukan di situs-situs gua baik di Indonesia pada umumnya maupun di Jawa (budaya Sampung) pada khususnya. Variasi tipe alat baik kerang maupun tulang produk penghuni Gua Kidang, lebih beragam dibandingkan tipe alat kerang dan tulang temuan dari situssitus gua pada umumnya(Nurani dan Hascaryo, 2011). Sebagian besar temuan alat dari tulang dan kerang di situs-situs gua hunian adalah serut bulan sabit, lancipan, sudip, dan spatula dengan pangkasan yang sederhana. Sementara itu, temuan artefak baik itu alat maupun perhiasan dari kerang, tulang, dan gigi di Gua Kidang lebih bervariasi seperti serut samping, serut cekung, serut bergerigi, serut bertangkai, serpih, bilah dari tulang dan kerang. Hal yang membedakan tersebut, disebabkan Gua Kidang tidak berkembang pembuatan alat dengan bahan batu, karena bahan baku tidak tersedia di sekitar Gua Kidang, dan kawasan karst Todanan.

Penerapan teknologi batu tampak jelas diterapkan pada pengerjaan alat dan perhiasan dari kerang ataupun tulang, terutama pada teknik pangkas dan struktur pengerjaan. Beberapa alat tulang dan kerang dikerjakan dengan pangkasan primer dan sekunder yaitu retus untuk penyempurnaan dan mempertajam alat. Dataran pukul, penyerpihan, pangkasan, dan retus diterapkan pada beberapa spesimen alat tulang dan kerang. Penyiapanpangkasan pada bagian dorsal dan ventral, utamanya tampak pada alat tulang yang dikerjakan lagi dari spatula menjadi lancipan, serut, ataupun alat serpihbilah. Penerapanteknologi alat batu pada alat kerang, adalah jenis serut cekung, serut samping yang tampak jelas pada pengerjaan sekunder untuk membuat tajaman.

Di lain pihak, sebagaimana telah disinggung pada jenis artefak 
spatula, menunjukan antara posisi temuan pada lapisan tanah (kronologi) dengan teknik pembuatannya, memberikan informasi yang signifikan. Teknik pembuatan spatula, berdasarkan posisi temuan, dari lapisan bawah sampai lapisan atas memberikan informasi tentang perkembangan teknologi. Temuan lapisan terbawah (tua) adalah temuan fragmen spatula dan beberapa calon spatula berupa lancipan dan sudip. Selanjutnya, lapisan di atasnya ditemukan spatula dengan teknik upam yang sempurna. Pada lapisan teratas (muda) temuan spatula dikerjakan ulang dalam upaya membentuk alat dengan fungsi yang berbeda.

\section{KESIMPULAN}

Berdasarkan uraian bab-bab sebelumnya, maka dapat disimpulkan beberapa hal berikut.

Perkembangan teknologi alat dan perhiasan yang diterapkan oleh manusia penghuni Gua Kidang adalah teknologi mesolitik dengan bahan baku kerang dan tulang. Hal tersebut memberikan informasi bahwa manusia penghuni Gua Kidang telah mengenal teknologi batu, walaupun lingkungan alam sekitarnya tidak tersedia bahan baku batuan dengan silikaan tinggi (bahan baku batu untuk alat, paling rendah memiliki kekerasan 5 skala mohs). Berdasarkan teori sistem, dan data teknomik yang ada di Gua Kidang, mencerminkan bahwa tingkat budaya didasarkan pada adaptasi manusia kala itu terhadap lingkungan alam sekitarnya. Binatang buruan selain sebagai sumber makanan, juga sebagai bahan baku alat seperti tulang atau gigi dari species Caninidae, Suidae, Cervidae serta cangkang kerang baik dari klas Pelecypoda maupun Gastropoda.

Perkembangan teknik pengerjaan dari lapisan bawah sampai lapisan atas memberikan informasi perkembangan teknologi baik artefak berlubang maupun spatula. Temuan artefak berlubang menunjukkan dinamika teknologi secara kronologis. Pada lapisan atas, artefak berlubang merupakan artefak jenis perhiasan, sedangkan pada lapisan bawah, cenderung dilubangi untuk kepraktisan membawa alat. Adapun temuan spatula memberikan informasi dinamika teknologi yang berbeda. Spatula temuan pada lapisan bawah, didominasi oleh temuan spatulaberupa lancipan dan sudip yang merupakan calon spatula. Selanjutnya temuan pada lapisan di atasnya, didominasi temuan spatula yang sempurna pengerjaannya. Temuan spatula pada lapisan atas adalah spatula yang dikerjakan lagi, sehingga menjadi jenis dan fungsi alat yang berbeda, seperti sebagai bilah, serut, atau lancipan.

\section{Ucapan terimakasih}

Terimakasih diucapkan kepada almarhum pak Rokhus yang semasa hidupnya sering berdiskusi dan memberi masukan dalam analisis artefak baik batu, kerang, maupun tulang. 


\section{DAFTAR PUSTAKA}

Doran, Jim, 1999. "Prospects For Agent-Based Modelling In Archaeology" in Archeologia e Calcolatori 10. pp 33-44.

Heekeren, H. R. Van.1972. Stone Age of Indonesia, VK -. The Hague: Martinus Nijhoff -Press.

Hidayat, Muhammad, 2007 "Laporan Akhir Orientasi Obyek Temuan BCB di Situs Kuwung dan Sekitarnya'Blora: Kerjasama Kantor Pariwisata dan Kebudayaan Kabupaten Blora dengan Balai Arkeologi Yogyakarta

James, Hill N. , 1977. Systems Theory and Explanation of Change, Explanation of Prehistoric Change -Albuquerque - University of New Mexico Press.

Miksik, John N. , 1984. "Perubahan Kebudayaan dan Kronologi Arkeologi di Indonesia", Artefak No. 1/1984. Bulletin Himpunan Mahasiswa Arkeologi FS - UGM. HIm. 28 - 43.

Moeljadi, 1984. Sedimentasi dan Posisi Stratigrafi Fosil Elephas pada Formasi Kabuh di Daerah Mulyorejo, Cepu, Blora. Yogyakarta: Jurusan Teknik Geologi Fakultas Teknik, Universitas Gadjah Mada.

Nurani, Indah Asikin dan J. Susetyo Edy Yuwono, 2008. "Gua Kidang, Pilihan Manusia Prasejarah di Kawasan Karst Blora" dalam Berkala Arkeologi Edisi Mei (1). Yogyakarta: Balai Arkeologi. HIm: 1 - 20

Nurani, Indah Asikin, dan Agus Tri Hascaryo, 2011. LPA Pola Okupasi Gua Hunian Prasejarah Kawasan Karst Blora Tahap V. Tidak terbit

Nurani, Indah Asikin, Hascaryo, Agus Tri, dan Koesbardiati, Toetik. 2012. LPA Pola Okupasi Gua Kidang: Hunian Prasejarah Kawasan Karst Blora. Yogyakarta: Balai Arkeologi. Tidak terbit

-, 2015. LPA Pola Okupasi Gua Kidang: Hunian Prasejarah Kawasan Karst Blora. Yogyakarta: Balai Arkeologi. Tidak terbit

Oakley, K. P. (1959). Man the tool-maker. Chicago: University of Chicago Press.

Soejono, R. P. , 1984. Sejarah Nasional Indonesia Jilid 1. Jakarta: Balai Pustaka , 2000. "Tinjauan tentang Pengkerangkaan Prasejarah Indonesia", dalam Aspek-aspek Arkeologi Indonesia. Jakarta: Departemen Pendidikan Nasional, Pusat Arkeologi.

Suhari, Dita Ayu, 2014. "Fungsi Alat Tulang dari Situs Gua Kidang, Kabupaten Blora, Jawa Tengah: Kajian Jejak Pakai", Skripsi. Jakarta: Departemen Arkeologi, Fakultas IImu Pengetahuan Budaya, Universitas Indonesia. 
Tanudirjo, Daud Aris, 1985. "Budaya Sampung Sebagai Budaya Transisi Masa Berburu dan Mengumpulkan Makanan Tingkat Lanjut ke Masa Bercocoktanam". Skripsi. Yogyakarta: Fakultas Sastra Universitas Gadjah Mada.

Wahyuni, Rindy Gita. 2013. "Tipologi Alat Cangkang Pelecypoda Situs Prasejarah Gua Kidang, Kabupaten Blora, Provinsi Jawa Tengah". Skripsi. Jakarta: Departemen Arkeologi, Fakultas IImu Pengetahuan Budaya, Universitas Indonesia.

Webb, C \& Allen, J. (1990). "A functional analysis of pleistocene bone tools from two sites in Southwest Tasmania". InArchaeology of Oceania, 25 (2), 7578.

Widianto, Harry, 1983. "Paleolitik Kali Oyo dalam Kronologi Pertanggalan Plestosen". Skripsi. Yogyakarta: Fakultas Sastra Universitas Gadjah Mada. 


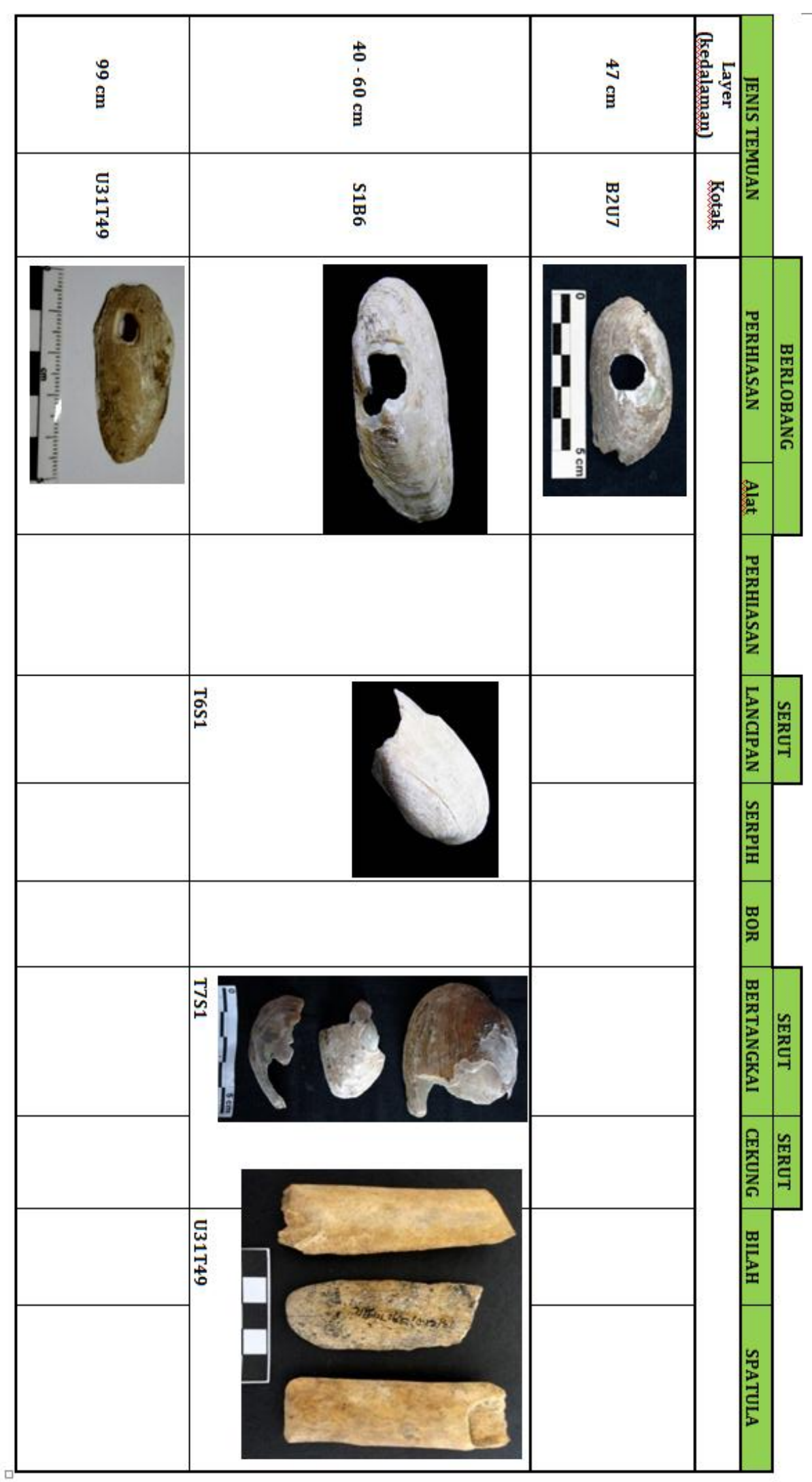




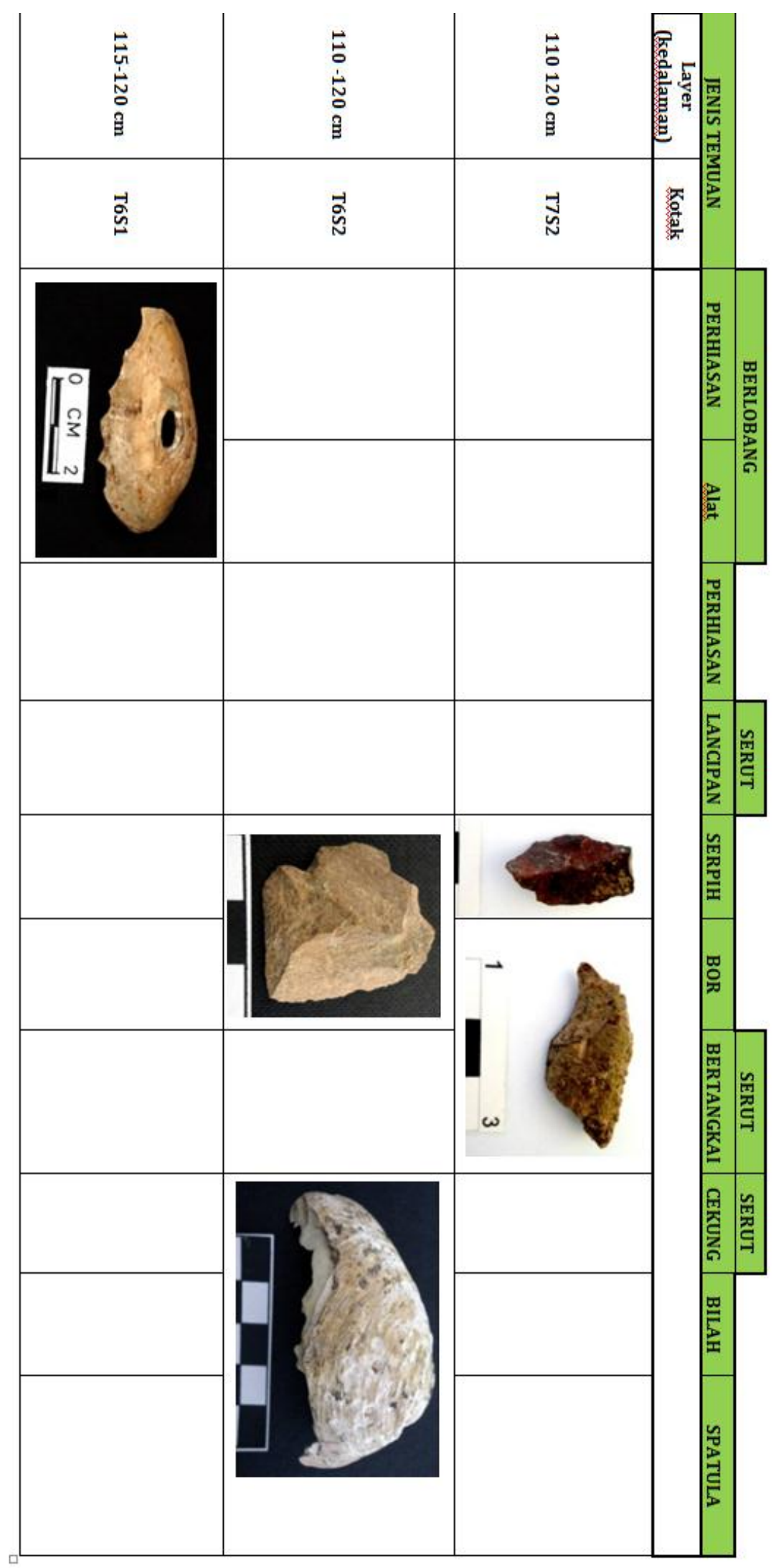




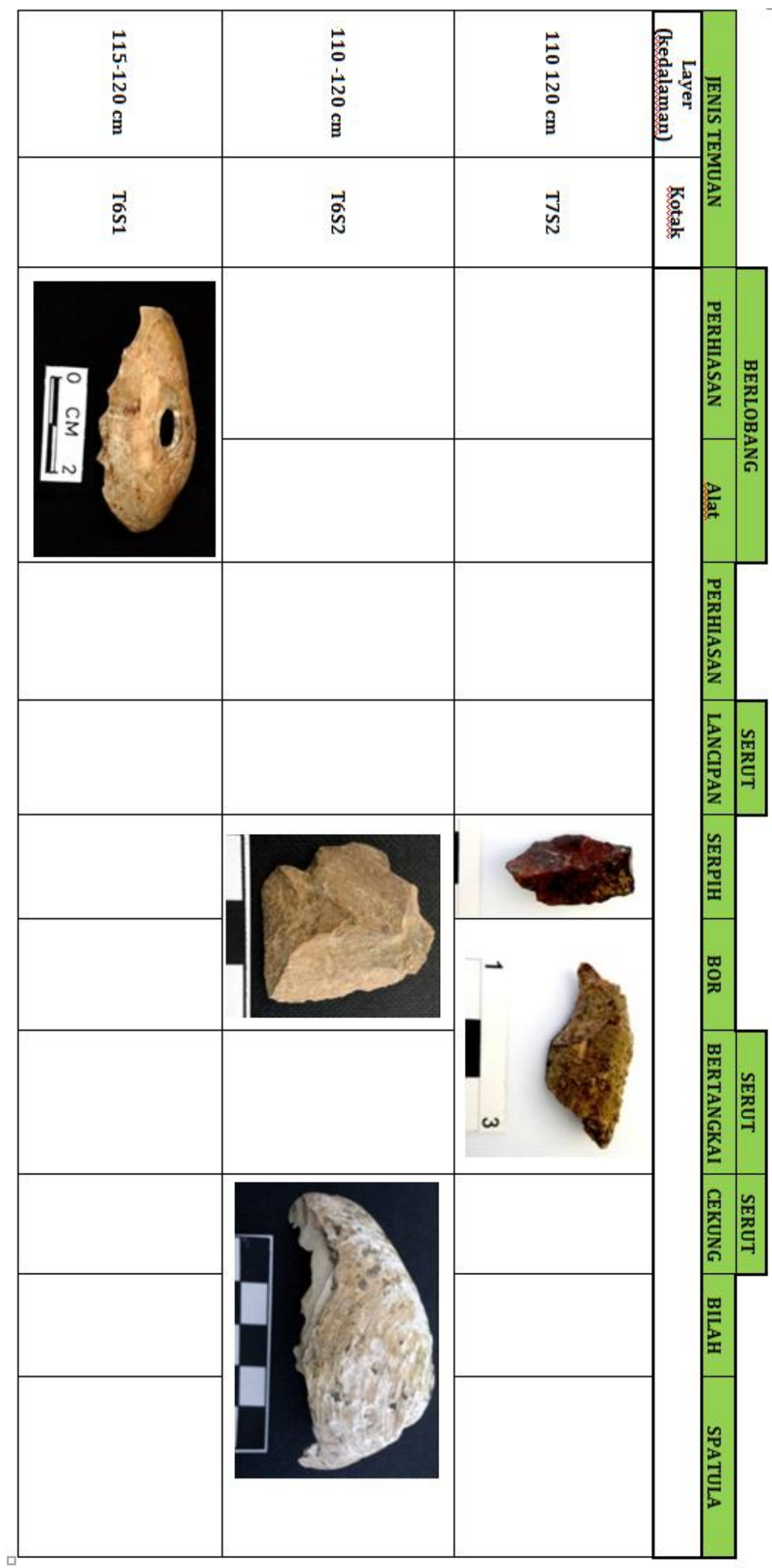

wn

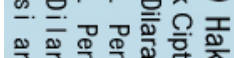

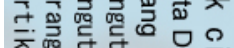

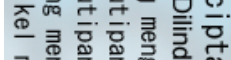

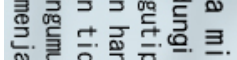
举衰

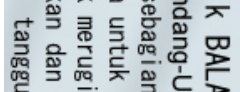

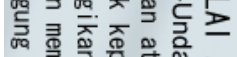

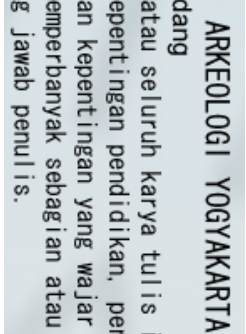

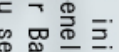

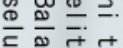

的

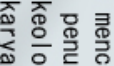

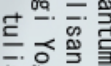

. 줏

כ. 충

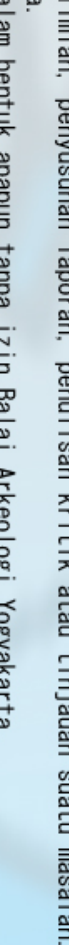




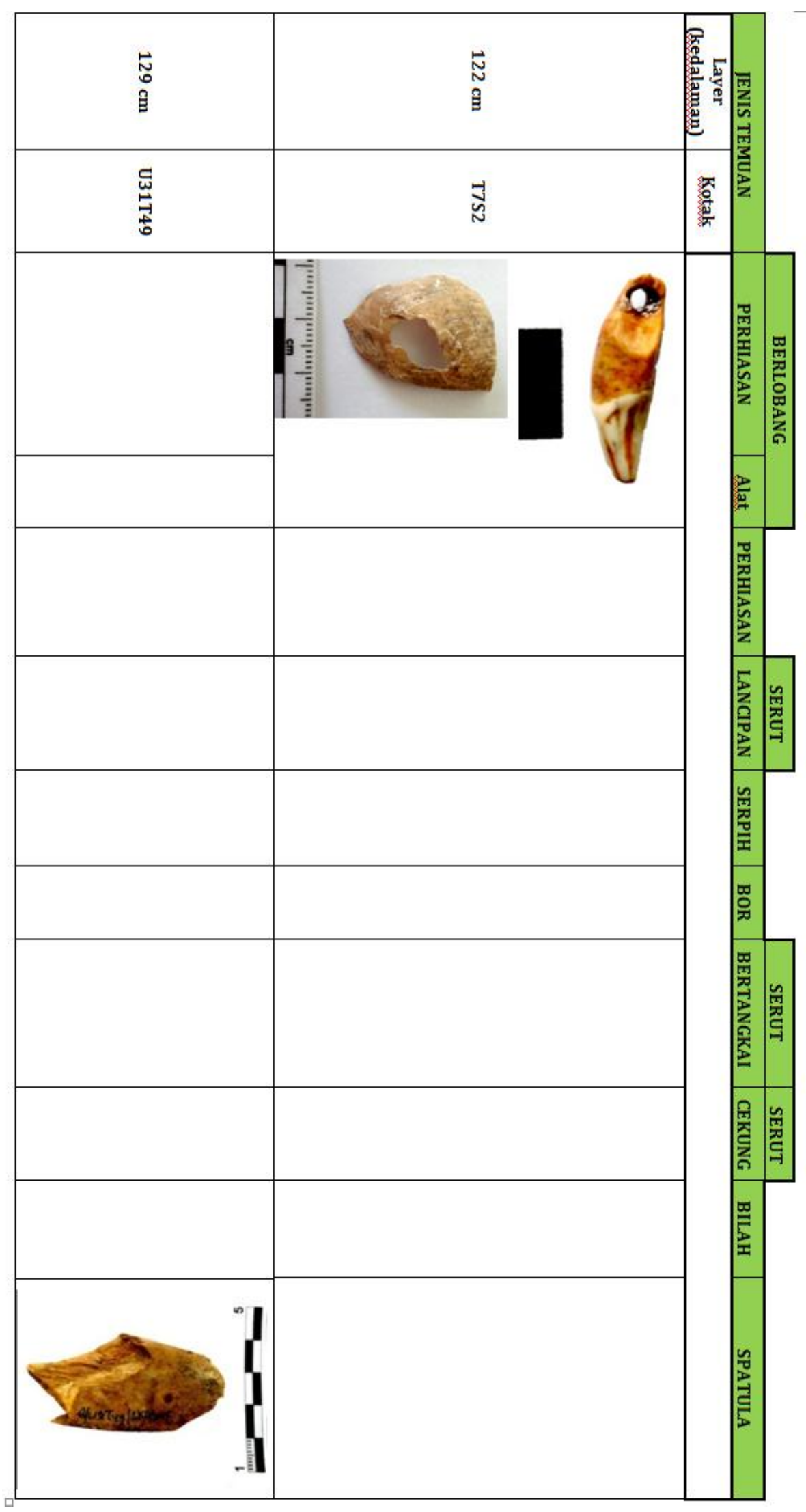




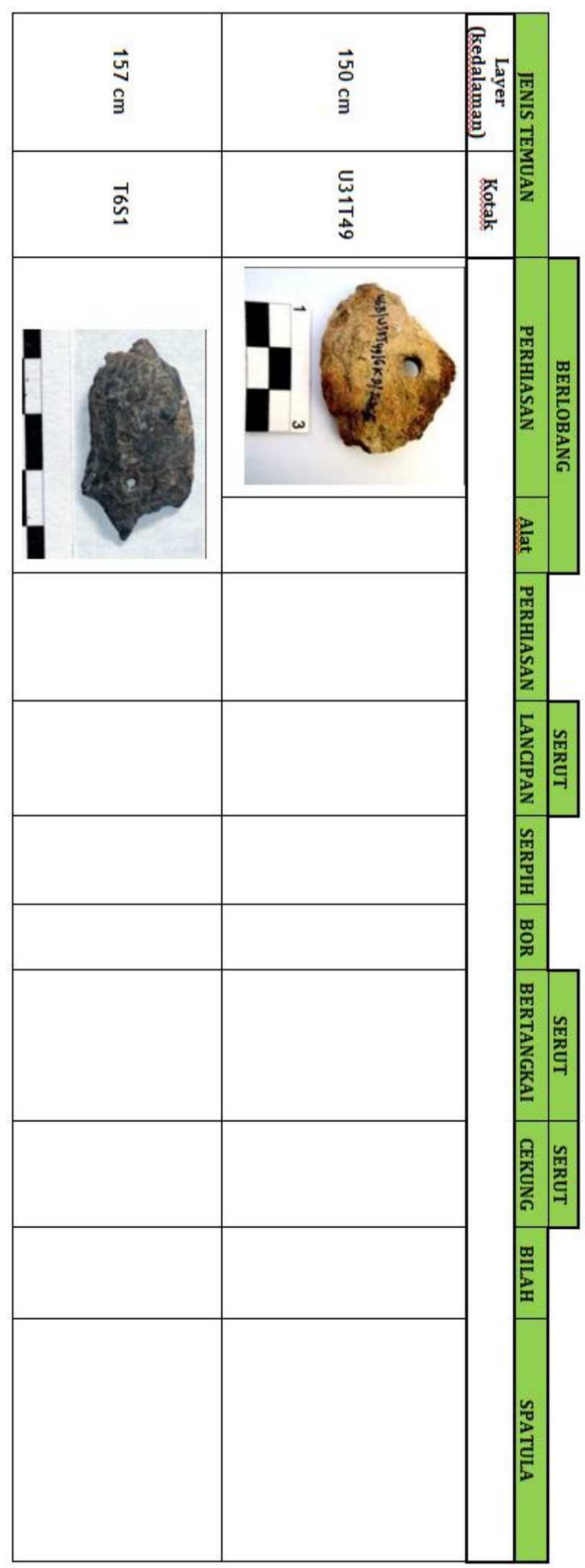

